\title{
Loan Interest as an Ideological Intention of the Capitalism
}

\author{
Asfar Askerovich Shaov \\ Vyacheslav Nurbievich Nekhay \\ Sergey Anatolyevich Titarenko \\ Zaur Makhmudovich Khachetsukov \\ Federal State Budget Institution of Higher Professional Education «Adyghe State University» (ASU), 385000 \\ Maikop, street Pervomayskaya, 208, Russian Federation; Email: nisadgu@yandex.ru \\ This paper considers the grounds for origin and development of the usurious nature of the capitalism phenomenon via social \\ and economic analysis means. The place and role of the loan capital market in terms of replacement of the civilization \\ paradigm and gradual ideological 'cracking' of traditional foundations of the Christian Europe, which happened under the \\ market's influence, and transition from the 'religious man' to the 'economic man' were defined. As a result, commercial relations \\ between individual feudal territories expanded, along with municipal growth and trade and money relation development, as well \\ as insulation and isolation of a feud was disrupted. There was a gradual shift from the conventional economic patterns, which \\ looked like a closed self-sufficient household of a non-market structure and involving a number of spoken and unspoken rules, \\ bringing different levels of its hierarchy together, towards a bourgeois (market), a system of highly specialized manufactures.
}

\section{Doi:10.5901/mjss.2015.v6n5s2p110}

\section{Abstract}

Keywords: Ioan interest, economocentrism, capitalism, loan capital market, traditional values, bank lending.

\section{Introduction}

One can come across rudiment economic theories in Western Europe mainly in works of Fathers of the Church, theologists and legal theorists - canonists of 14th-16th centuries. The trade was recognized in such works, provided the honesty, rightness and fairness were obeyed and usury (lending money on interest) was criticized. The church relied to some extent on Roman Law pattern; however, the church affected the law of lending and trade law overall and from the beginning mostly through its doctrine of fair price.

Non-involvement of the church in the process of market relation development in the Middle Ages was behind it. The medieval patristics did not regulate economic ideas as a separate scientific knowledge in a consistent way. Views and ideas, pertaining to the economic theory, were an integral part of the moral theology system. The ethical aspect of the economic theory appeared to be self-sufficient. While analyzing the history of relations between the individual and society, Erich Fromm says "There is not any place for any economic activity that would not be connected with the moral in the medieval theory". And further referring to Tawney "That economic interests are non-essential and should subject to the genuine goal of the human life, which is saving the sole" (Fromm, 1989).

This paper aims at proving the loan interest to be the ideological intention of the capitalistic system of management as a basic element of the west-European and further global world-economy.

\section{Methodology}

A polyparadigmatic approach, implying the use of techniques of classical, non-classical, and post-non-classical paradigms, forms the methodological ground of this paper. A comparative historical technique, which was developed within the classical Marxism, is applied for studying the development of the capitalistic system of global economic cooperation in retrospective. The authors rely on the economic central concept by J. Schumpeter and K. Polanyi in their exploration of the specific effect of the usury phenomenon on the development of the global capitalistic system. With a foundation of the libertarian theory by J. Locke and economocriticism by J. Hicks, the authors were able to reveal the role of the loan interest as an ideological component in the formation of the global commodity-money relation system, which 
became the universal type of global management towards the beginning of the 21st century.

\section{Findings and Discussion}

\subsection{Capitalism genesis in the paradigmal space of the West-European culture}

J. Schumpeter and other researchers acknowledged, despite all the attempts to step back from the specifics of an ideology of one period or another, the fact that any provisions of economic views were determined by the moral theology by a medieval researcher. The explanation for this fact may be found in the specifics of the medieval man's mind. Universality, Symbolism, and Hierarchy are primarily typical for such suprapersonal consciousness.

So, if M. Weber speaks of the spirit of capitalism as protestant ethic, Sombard about Judaism practices as a system that formed the capitalistic spirit for the most part, Marx as an added value and class exploitation, than Braudel shifts his focus from the mentality and class contradictions to profit maximization, while placing the capitalism inside a certain 'set', going outside its own borders and facilitating amplification of its own dynamics. The term 'capitale' itself, according to Braudel, a word from the Late Latin from caput - head, appeared in discussions of scholiasts, moralists and legal theorists of the 12th-13th centuries on the subject of interest and hiring the money, and it was used just in this context, i.e. the money bringing the interest.

A century later, we come across the following in sermons by Saint Bernardino of Siena (1380-1444): "this fruitful means of lucre, which we usually call capital" (Braudel). It will be further used along with such terms as 'wealth', 'money', 'fund', i.e. the final result of exchange. Even further as an adjective - capital funds, production capital, capital, until the Marx sees the means of production in this and combines all owners into a special class of capitalists. While not loosing its original meaning (capital as an interest), this term has had a negative vibe for the whole period of its history, and meant the only thing, i.e. a source of income, which was not earned by someone's own efforts, despite the sense that was ascribed to this term, depending on the time and other conditions. Nevertheless, capitalism could not be put within any certain borders of the historical periodization, due to its undesirable ideological baggage.

J. Baechler, a French expert in the theory of economics, makes a hypothesis in his fundamental work The Origins of Capitalism about the fact that neither Marx's, nor Weber's definition of capitalism makes it possible to define clearly its characteristic features, distinguishing it from any other phenomena that appeared in various cultures for the period of human history. He proves, using historical examples and facts, that a market, strive for profit, banks, bills and notes, interest and business corporations may not be considered the unique attributes of the capitalism. All these elements may be found in ancient agrarian civilizations as well. However, with view to the principal difference, which was inherent to such societies, capitalist merchants were considered as an inevitable evil in the best-case scenario in such agrarian civilization, as long as commercial activity was not prestigious at all at such times. Merchants were considered parasites, as long as did not manufacture anything and played an intermediary role in the economic processes, while satisfying the needs of thin elite and supplied warriors and priests, living in the cities, with excessive agricultural product, which was produced by farmers. While straining for the profit in the first place, such merchants earned a great deal of money, but did not have any social status or political power, which would correspond to their wealth (Lal, 2009,). Moreover, such situation did not shape any ideological space with the 'economic ideology' dominating and affecting the origin of a mass social and anthropological model of a 'homo economicus'. The presence of market elements was far from sufficient in individual civilizations for this purpose.

Thus an so, it is not the scope of market expansion, but a gradual ideological 'cracking' of traditional foundations of the Christian Europe, which happened under the market's influence, and transition from the 'religious man' to 'economic man' that is a defining feature of origin of capitalism in the European civilization. A change of the social 'statics' of the medieval society, which was expressed in the theocratic public hierarchy, involving its internal codified and canonized processes associated with relations of an individual man to the God, took place. A status in the form of power, money in the form of influence, and, mainly, the universal spirit in the form of a capitalistic commercial pattern of thoughts was necessary for a radical casuistic reappraisal of values of non-capitalistic varieties of the spiritual structure of the European culture.

"The circumstances did not undergo any changes, until the period of High Middle Ages: capitalists were able to create, at last, an economy in the Western part of the Eurasian continent, with the non-stopping pursuit of profits not only to be an acceptable activity, but a normal activity as well within such economy" (Lal, 2009). 


\subsection{Loan interest as a ground for developing trade and loan relations at the time of Renaissance}

V. Karpets in his Free Encyclopedia Traditio focuses our attention on the fact that capitalism actually derived from the trade, slave trade, and predatory wars. There is no way for the capitalism to originate in the independently existing and self-traditional society. It requires capitals that are free from control of the society and a principal predatory position towards others for its origin. This is only possible in the centre of crossing trade routes, free from control of land-based civilization (Maslov, 2009).

At the beginning of the $20^{\text {th }}$ century, or in 1919 to be specific, G. Feder finished his research of peculiarities of the Western-type financial system and revealed the leading role of the loan interest in such system; he stated the following: "An interest is a power source for a large capital. It is the interest, i.e. an unremitting continuous flow of benefits, just from the money domain, which does not require any efforts, that gives the power for the global money pillars to grow". J. Schumpeter defines the capitalism in a very concise way as a credit, i.e. as an interest - that we can add without any misinterpretation.

The economic order must implement the social order in the end. Moreover, both orders are defined as noninstitutionalized phenomena.

The man is perceived as a capital now. The economic logic has been spreading over all social phenomena. It originated in the society, and it engulfs the society completely in the end. It was pointed out already by K. Polanyi, who wrote: "With the advent of the market, the society becomes its assistant. Economic relations are no longer embedded in the public relations, but public relations are embedded in the economic relations" (Polanyi, 2008). That is where the sense of the bourgeois revolution lies.

By the time of Renaissance the state actually legalized various forms of money lending, while limiting the regulation of usury by an interest rate. Maximum 10\% rate per annum was announced in England in 1545. It was reduced to $8 \%$ in 1624 and to $6 \%$ in 1652 . Other states acted similarly. For example, maximum interest rate no higher than $5 \%$ was established in Netherlands in 1640, and maximum interest of $6 \%$ was established in France in 1601. Similar law was put into effect in Russia in 1754 and maximum interest was also 6\% (Pasynkov, 2013).

Any commercial set-up is driven by the system of beliefs or is determined by itself. We did not have to wait long for the theoretical grounds for the social and economic practice. Moreover, every one of numerous states of this time had its specifics. There are also common features that we come across everywhere to one extent or another. Just a few of them may be considered significant for the overall development, and other features followed the said ones. According to a number of experts, as announced by foreign and Russian researches, the interest loan is a key to understanding the change in the civilization paradigm. Since everything that happened at the time of Renaissance was a much significant transformation that the simple expansion of the money application area. Ending up in tight relation to the credit and governmental finance, money changed its nature. The Renaissance years were critical for the financial system development. This is not by accident, as long as financiers of this time faced an obstacle, which was unknown (or less known) to their Greek and Roman predecessors (Hicks, 1989, p. 139). A tremendous scope of financial transactions of Florentine companies, which were connected to banking and usury, brought may researchers to a conclusion that this activity is the central, if not the unique part of their activity. Western historians like Melzing, and Andre Seu consider their activity primarily as banking and usury, which allows Seu not to connect the origin of capitalism exclusively to the loan capital at all.

\subsection{Loan interest as an intentional basis for the global capitalistic system}

A. Seu traces the origin of capitalism to the $11^{\text {th }}$ century, while considering the trade, and even financial capital to be formed by the end of medieval times, which plays the ever-important role in the capitalism evolution. It turns out, in close examination, that the usurious capital is closely connected to the trade capital, when numerous loans were granted to civil and clerical nobleman, the Pope, kings, peasants and bourgeois, giving privileges to premier banking companies.

Repeal of the ban on usury led to renunciation of a spectrum of values that pulled the mankind out of the barbarism. The loan interest gave birth to the capitalism, and physiocrats stood at the origins of its theoretical reasoning. Thus and so, if representatives of mercantilism saw the wealth growth exclusively in free trade, and net product growth exclusively in exploitation of near-by nations or colonies, then physiocrats advocated free trade without any personal enthusiasms and did so in the first place, because they thought primarily of the freedom of internal trade, as well as because the natural order implies the freedom for everybody to sell or buy as one may think fit and not considering, whether it is inside or outside the country, as long as the natural order does not recognize any borders, and finally because the freedom ensures the best price. 
Ch. Gide and Ch. Rist pay special attention in their fundamental work A History of Economic Doctrines to the fact that physiocrats requested regimentation just for one type of trade - unique but not the most important - for money trade, i.e. for the loan. This is not surprising, as long as the interest has been embedded legitimately in the credit system for a long time then. We are wondering about the other thing: how one can rationalize this in accordance with the spirit of the historical period itself. In this context, it is reasonable to talk about a categorical structure of consciousness, existing and specific to the age of Enlightenment, which combines the elements of the mutually exclusive order. Therefore when this order is obvious, but the established scale of values is variable, this is indicative of its casuistry. The enlightenment 'drains' the soul, but prepares it for the possibility of constant cultural re-formulations (Gide and Rist, 1995).

Thus and so, Marquis de Mirabeau and Quesnay are non-consistent in their turn. On the one hand, they both accepted loans in farming, while considering the interest to be the expression of actual wealth growth, and net product just in this industry. On the other hand, the first one - Mirabeau - desired to forbid, or at very least limit the interest in trade, while speaking of the interest rather obnoxiously, calling the interest a tribute, charged by the 'parasitic class of rentier'. The second one - Quesnay - along with Mirabeau, considered the ground for the interest to be just the net land product, as long as any capital, according to him, may be used for land acquisition. However, he demanded just a legal limitation for the interest, while being less strict. Physiocrats are, apparently, consistent with this, as if the foreseen case to legalize the interest does not come into being, i.e. the capital is not invested in the land, but in industry or trade, which are 'fruitless' according to them, then it is obvious that the one may take interest exclusively from the borrower's pocket, and, accordingly, physiocrats had to judge it the same way they did with the interest on industrial and trade classes. Ch. Gide and Ch. Rist are still amazed by such obvious controversy (casuistry) of the founders of the science of economy, while appearing to be the fathers of the whole subsequent liberal economic school, their views on the role and functions of the state are controversial: "How can one explain such obvious controversy and such love for despotism in these apostles laisser faire" (Gide and Rist, 1995).

Turgot, who was actually a half-physiocrat (his final retreat from the ideas of the divine claim for ownership was one of the reasons), is the only one who admits the loan on interest openly and produces a physiocratic argument of a capital owner being able to place it into the land, and also being able to become any manufacturer, as long as the capital is the necessary basis for any entrepreneurship, and, consequently, giving his capital to the only party, offering him at least an equivalent to what he could gain himself, if involved in the manufacture directly, as an explanation. However, an assumption of any entrepreneurship presupposed to be productive, likely, shines through this argument. Indeed, Turgot tolerated infertility of the trade and industry not to the same degree as physiocrats.

Publication of tractates Some Considerations on the consequences of the Lowering of Interest and the Raising of the Value of Money by J. Locke, Defense of Usury by J. Bentham, essay Of Interest by D. Hume, and pamphlet Discourses upon Trade, principally directed to the cases of the interest, coinage, clipping and increase of money by Dudley North, which was published posthumously, were the major push towards the development of commercial bank crediting. A provision on scientific consistency and fairness of usury was finally secured in the economic thought, as a result.

Political and legal views of J. Locke are closely connected to his economic views, and the last are dedicated, in their turn, to the pressing issues of the economic theory. The title of a special economic work by J. Locke is distinctive in this context - Some Considerations on the consequences of the Lowering of Interest and the Raising of the Value of Money, where he speculates about the theory of money and their direct connection to the interest. "The natural Value of Money, as it is apt to yield such an yearly Income by Interest, depends on the whole quantity of the then passing Money of the kingdom, in proportion to the whole Trade of the Kingdom, (i.e.) the general Vent of all the Commodities" (Cherkovets, 1997). According to him, interest is high in two cases, such as: 1) when there is a great demand of money as credit resources, then money will be made scarce; 2) when money is little in proportion to the trade of a certain country. J. Locke and D. North wrote their works at the same time (1691) and relied on general views, as pointed out by Turgot, while presenting the interest on capital by analogy with a rent gained from the land, i.e. presenting the interest on capital as a form similar to the land rent. However, North did not stop there and advocated trade development and money yielding. According to North, money yielding for the purpose of trade development is the critical factor, facilitating interest rate lowering. It was assumed for such lowering to lead to further trade development. Therefore, North is pro natural lowering of the loan interest rate.

J. Bentham wrote his famous Defense of Usury in 1787. He was one of the economists to express his opinion on whether the state should interfere with personal contractual relations between citizens, or whether such interference of the government should be avoided, while providing adult capable citizens with the freedom to regulate their money accounts as they think fit. It became the reason why he attempted to investigate the matter of usury, the degree of reasonability and practicality of laws, limiting growth collection, and establishing the known rate, with exceedance of such 
rate leading to a criminal liability. He could not be left untouched by the fact, which seems unexplainable at first sight, about the consequences of the limiting law to be exactly opposite to the benevolent intentions of the legislator willing to protect the debtor's interests. "The result of my speculations on this matter, says Bentham, adds up to the following general principle: no man of ripe years, and of sound mind, ought, out of loving kindness to him, to be hindered from making such bargain, in the way of obtaining money, as, acting with his eyes open, he deems conducive to his interest. Consequently, no man ought to hinder from borrowing money on any terms he takes willingly" (Sigot, 2012, p. 72).

D. Hume published his Political Discourses, devoted to challenging issues of the political economy. Political Discourses were comprised of essays Of Commerce, On Money, On Interest, On the Balance of Trade, On the Jealousy of Trade, On Taxes, On Public Credit and abstracts from the letters in economic matters, where he advocates the freedom of international trade, and considers it as a mutual exchange of commodities of one nation by commodities of another nation. In his essay On Interest, Hume believes the interest to be a part of profit and high interest to arise from three circumstances: a great demand for borrowing; little riches to supply that demand; and great profits arising from commerce. Low profits and interest rate arise from the increase of commerce and industry; they serve in their turn to its farther increase. According to Hume, 'interest is the barometer of the state, and its lowness is a sign almost infallible of the flourishing condition of a people (Cherkovets, 1997).

A demand of 'primitive' usury decreases gradually, and such usury has become ineffective by then. A relatively high interest, negative attitude of the public, ambiguous borrowing terms, and, above all, the emergence of a bourgeois layer of entrepreneurs who were already in need of loans not as a means of payment or acquisition, but as capital to be invested in a business - all this led to civilized credit development, to the emergence of modern pioneer banks. The civilized crediting still means minimum interest rate at the loan credit market. The last attempt to break away from the bank loan under a credit agreement occurred in 1777, when the Parliament of Paris ruled to ban any type of usury, which was disapproved by the holy canons, and the French law continued to ban such usury constantly until October 12, 1789. This is a very remarkable historical fact. The ban on usurious interest activated financial bourgeoisie and France got its bourgeois revolution twenty years later, like Byzantium got a Crusade in response to the precautions against usurers. 1807 Act will establish a civil interest at 5\%, and 6\% with commerce; and anything above this figure was considered usury. A more modern French decree dated August 8, 1935 considered an excessive interest rate as usury leading to criminal investigation in the same manner. The public lost interest in usurious problems gradually with the development of manufactory and industrial capitalism in the $18^{\text {th }}$ century and decrease in the interest rate. Any control over the interest rate was off almost everywhere in the $19^{\text {th }}$ century (Pasynkov, 2013).

\subsection{Transforming the role of the loan capital in modern market relations: myth and realias}

The crucial role of the loan capital market under the de-centralized economy conditions is a modern dogma of the financial crediting, as long no company may be incorporated, function and develop without money borrowed. Unlike at the dawn of capitalism, it is rear for an entrepreneur nowadays to possess enough capital to satisfy the needs of his/her own business. However, the regulations and laws of a number of countries that still treat the idea of usury as need exploitation, week comprehension, inexperience or tumult of the creditor, implying the criminal liability, is slurred over.

John Richard Hicks, a winner of the Nobel Memorial Prize in Economic Sciences in 1972, distinguishes between two basic principles of a primitive non-market organization in his methodological work A Theory of Economic History. The first principle is based on the tradition, and the second one is based on an order. All other principles are combined derivatives of these two principles. There was a gradual shift from the conventional economic patterns, which looked like a closed self-sufficient household of a non-market structure and involving a number of spoken and unspoken rules, bringing different levels of its hierarchy together, towards a bourgeois (market), a system of highly specialized manufactures. The essence of these changes is that the 'market' producer is oriented on an economic benefit of the production. Such production, according to J. Hicks, must be supported by such social institutes, making the trade economy impossible without them. A consensus, exchange and ownership right are the basic elements of the market economy, making functioning of this area simply impossible without them. However, these institutes are the ones that cannot be supported by the conventional economy. Another simple reason is that a new type of man, whom we define as the 'homo economicus', i.e. the man that was generally described according to the tradition, leading back to Marx and Weber, as a man guided by economic rationality concepts, is required for the market economy to function smoothly. This man specialized historically in trade; in our case, we are not speaking about individual exchange events in the form of irregular trade, which has been certainly observed since the ancient years, but about the origin of the very specialized trade, which is indicative of the beginning of a new world. According to J. Hicks, such new world could originate due to a number of reasons, one of them being the formation of an effective banking system. It should be pointed out that Hicks 
himself did not see anything forbidden in interest-bearing credit, but only an extra guarantee for the borrower; however, we are primarily interested not in personal feelings of Hicks regarding the loan interest, but in his explanation of its wide spread at the end of Middle Ages. According to Hicks, the increasing need for credit pushed traders to 'find their own ways of minimizing financial risks, which would not depend greatly on court rulings' (Hicks, 1969, p. 112), on the one hand, and trade economy blossoming, on the other hand, depended on expanding the circle of trustworthy borrowers. The market was expanding as far as intermediary relations grew, with a bill of exchange being their warranty. The reanimated bill of exchange made it first trip in Europe in 1410. With time in 1631 the Republic of Genoa was granted by the Pope Urban VIII acceptance of long-term promissory note transactions (changes et rechanges), i.e. usury, which was immediately admitted as a legal practice.

And numerous fairs in Paris, Lyon, Champagne, Vienna, Amsterdam, Medina del Campo in Castilla, Frankfurt-amMain, Leipzig, Besanyon, Chambery, and especially Piacenza gave rise to a credit, and the credit was reimbursed just there. A part of debts outstanding was covered by the promise to pay them at a certain place using a bill of exchange, as long as payment contango was 'deposito in a year at the next fair, which was usually paid from $10 \%$ per annum (2.5\% per three months). Thus, the fair invented the credit", but who were those that secured the credit? "However, what was, to the contrary, a universal phenomenon, it was the emergence of people lending out money and usurer networks - Jewish, Lombards, or natives of Cahors, or monasteries in Bavaria that specialized in granting loans to peasants" (Braudel, 1992).

While coexisting in parallel, fairs and exchange houses, banks and shops, wholesale by merchants-negotiants and middlemen bargainers-deliverers, money exchangers and usurers - all was transformed into a giant and insane sale and resale market. By the times of Enlightenment, the entire Europe was involved completely into new forms of finance and credit, was fully subordinate to bank and exchange house life to be able to change itself.

It was the $18^{\text {th }}$ century, when the production increased at least five times, as compared to the $17^{\text {th }}$ century; Braudel talks about a disruption of isolated economies, of over-demand and total exchange, he writes in conclusion: 'In the 18th century everything increased again: money conquered Europe and even the whole world.' As far as the business specialized in a certain mediatory finance activity, we can speak with good reason of the origin of banks. According to Hicks, interest legitimization coincides with the incorporation of the first banks, as long as their profit depends directly on the loan interest rate. Florentine banks of the $13^{\text {th }}$-14th centuries are the most popular among them ('bank' means 'bench' in Italian, a place, where money exchangers displayed their coins in bags and vessels. Usurer's name in ancient Greece had the similar meaning - trapesites - of Greek trapeza - table; money exchangers and usurers sat at their tables at markets. Here comes the word 'bankrupt' - of Italian - banca. When a money exchanger abused someone's trust, his table was broken down - banco rotto - literally, table overturned); then again, they were not so reliable in the first place, and the attracted funds did not bring the anticipated profit. A popular bank Bardi and Peruzzi was the most pompous in 1342; however, Florentine banks were more successful already at the times of Medici Family. An example may be Monte de Paschi di Siena bank, which is active even today. It has the door plate saying: 'Founded in 1472.' Crediting on loan was considered a great sin at the time, therefore, parties to such agreements tried to conceal the fact of interest available. Combining a lending transaction with a currency exchange transaction was the most popular way to conceal the interest. Nevertheless, Hicks believes, referring us to a number of research papers, there are evidences of the interest over 20 per cent only to be considered usurious among the Florentine bankers in the $14^{\text {th }}$ century.

\subsection{Banking system as a mechanism for legitimizing usury}

Banks accumulated considerable material resources, which they, naturally, lent on a very high interest. Then, the credit was employed to a very small extent in the production area, which was compressed by guilds. The usurious capital credited luxury expenditures of feudal lords (buying luxuries), and, ultimately, military (colonization) expenditures of states. Because of continuous wars, Louis XIV postponed establishment of the royal bank and was forced to resort to services of financiers (traitants et partisans), who lent money (as secured by bills of exchange) for tremendous expenses of his armies abroad (Braudel, 1992,).

Powerful banking institutions established their own trade and production companies (mineries, etc.), and large merchants invested their free capital in the credit and usurious industry. Thus trade and banking and usurious firms were established that played an important economic and political role in feudal Europe. Growth of the capitalistic management with the usurious capital dominating, culminates the feudal stage with its conventional forms of ownership. Landlords found themselves in debt, as long as loans were usually granted on the pledge of land. Interest-free types of crediting existed within the merchant's society; however, a large businessman resorted to usurer's money for the most part. A fundamental difference was that a trade transaction, which was composed this way, had to ultimately ensure the rate of 
profit obviously exceeding the interest rate. Defoe gave an opinion on this matter that the profit came to naught even for the 'legal' five per cent rate.

Credit was used inefficiently and not only was it not a factor of expanded reproduction, but even caused production decline, as long as a significant part of the feudal lords' profit, and small-sized producers in particular, was engulfed by interest payment to the usurers, and, consequently, could not be invested in their own business. The usurious capital did not facilitate pre-conditions for a capitalistic production mode, until the formation change took place. As soon as the usurers accumulated tremendous money resources, they transformed immediately from the usurious capital into a functioning capital, which was invested in capitalistic companies. One way or another, the key point is that the capital circulated in a closed circle. M. Kennedy, an active lobbyist of the idea of creating an interest free money system addressed this circumstance in her book Interest and Inflation Free Money; she believes that a mechanism leading to capital accumulation in hands of less and less people is among the adverse effects of the interest economy: "Within our monetary system we allow the operation of a hidden redistribution mechanism which constantly shuffles money from those who have less money than they need to those who have more money than they need" (Kennedy, 1995).

Thus and so, trade and usurious capital of the Medici's firm credited actively wool industry of Florence. Moreover, with their branches in many European cities and great resources in their possession, Florentine woolen cloth wholesale traders were able to procure crude wool in England and sale finished textiles at distant markets. For examples, transactions by the merchant's firm of the Boni brothers of Montauban (14th century) included issue of loans against pledged bills, movable property, land, acceptance of deposits on interest, tax and tithe farming, textile, footwear, jewelry, spice, arm trading etc., and drug, wax candle and confectionery production, horse rental, funeral services etc. Trading and credit and usurious transactions were also interconnected in the activity of the largest banking houses of the Middle Ages, such as of Medici, Fugger, and Welser (Shaov, 2011).

It was France that became a country, where the usurious capital prevailed significantly over the industrial and agrarian capital, while taking the crucial role in the commercial life of the country. Already before the 19th century, rentier became the dominating economic class, while living exclusively off interest on the capital, which was placed into securities, primarily public bonds. The power over French national economy management was usurped by ca. 200 largest bankers. Moreover, loans to foreign states ensured to the French bankers income that was not associated with any industrial risk, while diverting tremendous funds from the domestic industry. Before the end of the $19^{\text {th }}$ century, France was not only behind England, but also US and Germany in terms of the industrial development pace. The French capital responded to worsening its position in the industrial world by strengthening its activity in the lending and international crediting business.

Capital growth at three largest French banks - Crédit Lyonnais, Comptoir National Société Général: 1870 - 627 , $1890-1510,1909-5,250 \mathrm{mln}$ francs, is illustratory. French finance capital was accumulated around banks, and not industrial monopolies. The Banque de France became its main center - 200 largest shareholders of the Banque de France (200 famous families!) were the ones to make up the elite of the national financial oligarchy. The added product formed a thin group of privileged individuals, now and then. Adolphe Thiers wrote in the 19th century: "in a country like France, it is known that ... there no more than two or three hundred wealthy dynasties per twenty million families" (Hicks, 1969).

The Banque de France was a unique case of concentration of the financial capital in the national scope.

French export capital increased more than four times, and no more than three times with the industrial production, giving the pas of industrial investment export to England, but retaining the leading role of global usurer. The history of global economy development coincides with the history of the largest trade speculations, which, are interconnected, in their turn, with the history of global wars.

For example, before the World War I, no more than 9.5 bln francs out of 104 bln francs of French security value pertained to the French industry and commerce, while the rest was bonds of various investment abroad. The international usury left a parasitic imprint on the overall life of the country. A thin layer of rentiers, living exclusively of interest on bond of international loans, free from any industrial or commercial risk, stayed in France forever. The usury deformed the economy not just in France, but also in those countries receiving Parisian loans. Shortly before the World War I, just 10 bln out of $42.5 \mathrm{bln}$ of foreign investment of France found commercial application, while the rest of the money was primarily used to arm future allies against Germany, 12 bln of borrowed francs were taken up by Russia, and a number of plants and manufactures, the Trans-Siberian Railway, Kiev, Saint-Petersburg and Odessa trolley networks were established, using this money. Nevertheless, they were paid enough in the Russian blood - the czarist regime suppressed the 1905 revolution, and executed an unprepared attack in August 1914 in East Prussia, at the very beginning of the World War I, which ended in a disaster, but allowed for a part of German forces to be pulled back from Paris. As long as an interest on Russian loans is higher than usual (up to $14 \%$ per annum vs. 2), such loans were 
extremely popular in France. Up to $10 \%$ of the nation held Russian bonds at the beginning of the World War I, and thousands of Frenchmen sold their land and houses to acquire such bonds.

Despite the fact that France acquired large colonies in Africa, South-Eastern Asia and Oceania and built an empire with its territory being 17 times as big as the metropolis in the $19^{\text {th }}$ and at the beginning of the $20^{\text {th }}$ century, the French financial capital was not interested in any productive use of colonies, while cashing in, primarily, on exploitation of the debtor countries. Therefore, the colonies played a much smaller role in the French economy vs. the English economy. Before the World War I, just 13\% of imported goods by France and less than 10\% of imported capitals were exported to the colonies. Just $9.5 \%$ of the French import came from the colonies. Primary income was gained from the usury, and France maintained an army, which was almost equal in manpower to the German army, while its economic potential was significantly inferior to the German one.

However, according to M. Loiberg, the social and economic role of the usurious capital is very ambiguous. The usurious credit facilitated bankruptcy of middle-sized and small feudal lords, and, therefore, freedom of peasants. To the contrary, loans to various countries strengthened the feudal system. Having discovered and conquered America - at the expense of money borrowed from the Fugger bankers from Augsburg - economically undeveloped Spain became a superstate in the $16^{\text {th }}$ centuries, and, slowed down liquidation of feudal system in Western Europe for at least a whole century. However, it became so weak in the end that it took a pounding just from four Dutch battalions. It happened in 1557, when the Spanish king refused to pay any interest, referring to the ecclesial ban. Let us name a few more facts out of numerous historical examples, where the credit is connected directly to the war. Credit expansion to the British kingdom is associated with the Ricardi merchants of Lucca, who backed up the conquer of Wales by Edward I; soon after, the Frescobaldis of Florence lent money to Edward II for his was with Scotland; the commencement of the Hundred Years' War is facilitated by banking and usurious houses of the Bardi and Peruzzi, who made military operations of Edward III against France possible. However, the British campaign was fatal for the Bardi family. B 1345 r. Edward III ought an enormous amount of money at the time to the Bardi family, along with the Peruzzi family - 900 thous. florins to the Bardis and 600 thous. florins to the Peruzzis. The amount, which outnumbered the capital of both companies, is yet another evidence of the fact that they used their contributors' money to grant such giant loans. The place of the Florentine bankers was soon occupied by their rivals - Genoa and Venice (Loiberg, 1997).

The power grew, and the bourgeoisie gained public strength in proportion to the growth of a financial economic sector. Industrial activity picked up its pace, communication routes were improved, and trading networks broadened along. The latent process of combining workshops and capitalistic manufactures into one production accelerated.

Under the competitive pressure, wholesale buyers brought under handcraft production of woolen fabrics and practically remade it significantly into a hired and capitalistic industry, while leaving a guild handcraft sign-board.

The whole preproduction cycle, including fabrication, washing and cleaning of wool, and weaving makes the production more and more differentiated, where hired labor with days' pay is used exclusively. Thus, a handcraft guild was combined with a capitalistic company (manufacture) here, based on the hired labor and step-by-step division of labor. 70 pieces of cloth per year were produced at an average Florentine cloth-making company in the 14th century, operated by 40 hired workers (a guild produced hardly a half of that).

Similar hidden capitalistic corporations also appeared at other production facilities across Europe, in silk industry in Italy and France, metalware production in Nurnburg, and especially in out-of-city industries like ore mining etc. "Functioning of a capitalistic company under the pretense of guild handcraft is usually connected with the special economic conditions available, such as consistent credit, long-range raw-materials and broad sales market and labor market. Trading and usurious capital of North Italy created the first capitalistic industrial production in the history" (Sombart, 1998).

\section{Conclusions}

So, it should be said in conclusion, first of all, that large money capitals were accumulated as a result of trade. Usury developed. Usurers issued loans to feudal lords and kings, which were in constant need of money. They also lent money to small producers - peasants and craftsmen to pay compulsory payments. The very Catholic church became the largest usurer with time, while issuing loans on the pledge of land and expanding its land holdings this way.

Trade and usury development was accompanied by growing monetary circulation. Large feudal lords had the right to stamp out their own coins, 80 feudal lords held this authority in France in the 13th century. The variety of coin systems gave birth to money changing. Money changers -bankers did not only change money, but also transferred and deposited money. The money-changing business became a seed of banking credit, and banking operations. Merchant's and usurer's capital was the first type of monetary capital. As a result, commercial relations between individual feudal 
territories expanded, along with municipal growth and trade and money relation development, and insulation and isolation of a feud was disrupted. There was a gradual shift from the conventional economic patterns, which looked like a closed self-sufficient household of a non-market structure and involving a number of spoken and unspoken rules, bringing different levels of its hierarchy together, towards a bourgeois (market), a system of highly specialized manufactures.

\section{References}

Bibler, V.S. (1997). Vek Prosveshcheniya i kritika sposobnosti suzhdenia. Diderot and Kant. [The Enlightment and critisim of reasoning capabilty]. Retrieved from http://www.culturedialogue.org/drupal/ru/node/415 [in Russian]

Braudel F. (1992). Civilization and Capitalism, 15th-18th Century: The perspective of the world. Vol. 2: The Wheels of Commerce (pp. 189; 214). - Los Angeles: University of California Press

Braudel, F. (1986). Tsivilizatsiya i Kapitalizatsiya, XIV-XVIII v.v [Civilization and Capitalism, 15th-18th Centuries. Vol. 1: Struktury povsednevnosti: vozmozhnoe i nevozmozhnoe [The Structures of Everyday Life: the possible and the impossible] - Moscow: Progress(pp. 623). [in Russian]

Cherkovets, V. N. (1997). Vsemirnaia istoria ekonomycheskoi mysli. [The world history of economic thougths]. Retrieved from http://www.booksite.ru/fulltext/mys/lye/cjn/omik/index.htm [in Russian]

Fromm, E. (1989). Begstvo ot svobody [Escape from freedom] - Moscow: Progress,(p. 54). [in Russian]

Gide, Ch. \& Rist, Ch. (1995). Istoriya ekonomicheskikh ucheniy [A History of Economic Doctrines] - Moscow: Ekonomika (pp. 65, 437). [in Russian]

Hicks, J.R. A. (1969). Theory of Economic History (p. 112; 139; 148; 149). Oxford: Oxford University Press

Kennedy M. (1995). Interest and Inflation Free Money. Retrieved from http://userpage.fu-berlin.de/ roehrigw/kennedy/english/Interestand-inflation-free-money.pdf

Lal, D. (2009). Vozvrascshenie "nevidimoy" ruki: Aktualnost klassicheskogo liberalizma v XXI veke [Reviving the invisible hand: the case for classical liberalism in the twenty-first century] Translated from English. - Moscow: Novoie Izdatelstvo ( $\mathrm{pp} .20)$. [in Russian]

Loiberg, M. Ya. (1997). Istoria ekonomiki [History of economics]. Retrieved from http://www.mnoogoknig.ru/bookbox_94324.html [in Russian]

Maslov, O.Yu. (2009). Mirovoi krizis i ssudnyi protsent [Global crisis and loan interest]. http://www.polit.nnov.ru/2009/09/11/ssood percent35/ [in Russian]

Pasynkov, A.S. (2013). Fenomen rostovshchichestva: ot Vavilona do globalnoi finansovoi sistemy [The phenomenon of usury: from Babylon to the global financial system]. Retrieved from http://ekvi.ucoz.ua/load/1-1-0-16 [in Russian]

Polanyi, K. (2002). Velikaya transformatsiya. Politicheskie i ekonomicheskie istoki nashego vremeni [The great transformation: the political and economic origins of our time] http://all-ebooks.com/2008/09/01/velikaja-transformacija-politicheskie-i.html [in Russian]

Shaov. A.A. (2011). Chelovek ekonomicheskii v ideologicheskom prostranstve evropeiskoi kultury [Homo economicus in the ideological space of European Culture] (pp. 52). - Maikop: IP Nazarov [in Russian]

Sigot N. (2012). John Stuart Mill versus Jeremy Bentham: between the liberalism of freedom and the liberalism of happiness/ Freedom and Happiness in Economic Thought and Philosophy: From Clash to Reconciliation (pp. 67-84). N.Y.: Routledge Frontiers of Political Economy

Sombart, W. (1998). The Quintessence of Capitalism: A Study of the History and Psychology of the Modern Business Man (pp. 231). New York: Taylor \& Francis 